\title{
Personal Deixis Implementation in King Fahad's Speech to the International Troops During the Second Gulf War (1990/1991)
}

\author{
Tahani Saleh Alabdali \\ College of Languages and Translation, English Language Department, Imam Mohammad Ibn Saud Islamic University IMSIU, Riyadh, Saudi \\ Arabia
}

Email address:

s tahani@hotmail.com

\section{To cite this article:}

Tahani Saleh Alabdali. Personal Deixis Implementation in King Fahad's Speech to the International Troops During the Second Gulf War (1990/1991). International Journal of Language and Linguistics. Vol. 7, No. 6, 2019, pp. 327-337. doi: 10.11648/j.ij11.20190706.21

Received: October 11, 2019; Accepted: November 14, 2019; Published: November 25, 2019

\begin{abstract}
In this paper, the use of some deictic expressions -in the late King Fahad bin Abdulaziz Al Saud's speech to the international troops during the Second Gulf War- and its various implications on the message being delivered by the speaker, and its possible effect on the hearer are examined. Since the term deictic expression covers many linguistic items that could not possibly be comprehensively investigated in one paper, the focus of this paper is on personal pronouns which are analyzed in terms of frequency and implication in order to arrive at a better understanding of their implementation in such a historically significant political speech. The findings support the notions of critical discourse analysis regarding the relation of politics, power, ideologies, and discourse. The use of personal pronouns in this text was sometimes found to convey underlying messages which were intended to persuade the targeted audience of the speaker's decisions and at the same time justify certain major measures that were taken.
\end{abstract}

Keywords: Critical Discourse Analysis, Political Speech, Personal Pronouns, Deixis, Historical Speech

\section{Introduction}

"The single most obvious way in which the relationship between language and context is reflected in the structures of languages themselves, is through the phenomenon of deixis." [14] p. 54. Therefore, in order to investigate the reflections of an important historical era, i.e. the Second Gulf War (1990/91), the linguistic use of deixis in a significant speech of that time has been examined in this paper. Thus, this paper investigates the use of personal deictic expressions particularly personal pronouns- in the speech delivered by King Fahad bin Abdulaziz Al Saud the late king of Saudi Arabia (1982-2005). The speech was a spontaneous one and it targeted the international alliance troops situated in Saudi Arabia at that time to free Kuwait from the Iraqi invasion. The speech was also used as a media vehicle to notify the world of the Saudi Arabia's stand and justification of such. The speech was widely distributed and seriously taken by the international community [15]. At the time, having an Arab state gathering international forces to fight another Arab state was judged by some Arab governments and peoples as treason to their Pan-Arabism and to the Islamic religion. And since language can be used to arrive at effects that can only be obtained through political practice, such as consensus, authority, legitimacy [3], we believe that many linguistic expressions including deixis were implemented in the late King's speech in a way to legitimize the action of force and to defeat allegations of treason.

\section{Literature Review}

\subsection{Previous Studies}

There is a number of studies that have tackled similar political speeches from a pragmatic and/or discourse analysis perspective. In this section, I attempt to review a few of the most prevalent studies in this field.

Adegojul [1] studied the implementation of person deixis in the political discourse of Nigeria's "June 12" conflict. He believes that in addition to the referential function of deixis, they are used by politicians to establish and promote their 
ideological positions on specific issues. Therefore, the researcher concluded that the use of personal deixis, like pronouns, in the text been investigated and in other political ones is deployed in a way that defines power relations among the interlocutors not only in a particular text but in the society as a whole.

Khalil [13] examined the use of discourse deixis in some American political speeches. According to the researcher, demonstratives are the most prominent spatial deictic expressions used as discourse deixis. He concluded that the genre under investigation is full of discourse deixis for underlying purposes. One of these purposes is to clarify preceding parts of the speech in order to emphasize them. Another reason is to refer to a forthcoming part of the speech. He also argued that politicians are, somehow, unconscious of the matter of proximity of the deictic expressions this and that, which were used in the same way without clear difference.

Quinto [17] conducted a stylistic study of deictic expressions in President Benigno Aquino III's October 30th Speech. The researcher used the English translation of the televised national address to investigate how personal, temporal, spatial, and social meanings were deployed. He believed that the deployment helped creating a deictic field in which the Filipino people were at the deictic center and the President and his critics were in binary opposition. He argued that not only personal deixis, but also temporal, spatial and social deixis help political speakers persuade their audience in their favor and ultimately make their political discourse powerful by convincing the audience to accept their views and position in relation to the political discourse.

Eragbe and Yakubu [6] investigated the use of deictic expressions in some Boko Haram insurgency reports by the media. The analysis revealed that deictic expressions give temporal and spatial orientation of the actors in relation to the context, including the prospective audience. Such expressions were used in these reports to fuse participants, place and time in order to give the reader a better understanding of the discourse.

Gjergji [8] studied the types and choice of deictic expressions in the novel "The Broken April" crated by Ismail Kadare. The researcher adopted the framework and classification suggested by Levinson (2004). Instead of creating a corpus of personal, spatial, and temporal deixis, count the number of their occurrence, and attempt to interpret their significance and implication in the text, the researcher chose to analyze selected utterances from the chosen text. He concluded that deictic expressions are a vital link between the real life and what is being said or written, i.e. the text. Therefore, a comprehensive interpretation of utterances is highly dependent on understanding the circumstances surrounding the utterance being interpreted. Although the researcher's work focuses on a different genre than the present one -literary rather than political- they both emphasize the importance of closely analyzing deictic expressions and investigating their connection to the real world, speakers' intentions, and audience.
Hamdaoui [10] investigated the use of the pronoun 'we' in 14 speeches delivered by President Obama, the President of the United States, in 2009. All 14 speeches targeted the American people in an attempt to persuade them of governmental suggestive measures to deal with the 20072009 Financial Crisis. The results emphasized the power gained from using personal pronouns in political discourse in calculated ways. For the speeches under investigation, the pronoun 'we' was used to strengthen the sense of unity between the speaker, Presidents Obama, and the American people, and to create a positive image of the American nation.

Ivanova [11] analyzed the victory speech pronounced by president Michelle Bachelet in the Republic of Chile. The paper focused on the deictic expressions used in the speech. The researcher claimed that the use of personal pronouns with undefined clear references might be intended by the speaker to highlight the values of solidarity, belonging, and bonding with the people of his country. As for spatial and temporal deixis, the researcher spotted explicit reliance toward proximal, rather than, distal references, which again can be interpreted as the speaker's intention to indicate rhetoric closeness to the people of his nation.

Carreon and Svetanant [2] conducted an investigation on the political speeches of the Thai Prime Minister Gen Prayuh Chan-ocha following the ideas of Van Dik's concept of political discourse analysis. They categorized the most frequently used words in his speeches into themes and analysed the ways they were employed in text. The results revealed that the use of language was directed towards the justification of the political, economic, and social agenda designed by the government. Another interesting finding was related to the change of language used in delivering the speeches. The researchers claim that when the language of the speech was English the implementation of linguistic tools was towards enhancing the image of the Thai government in the eyes of the international community.

Khalifa [12] explored the use of deictic expressions in sample speeches of President Donald Trump. She calculated the frequency of use of each type of deixis and compared their uses. Based on the frequency and types of use, the author conducted qualitative discursive analysis to investigate the desired impact on the targeted audience and their influence on the choice of deixis by the speaker. The findings suggested that the use of certain personal pronouns over others might imply the speaker's psychological state, e.g. insecurity, instability, and anxiety. Moreover, the researcher found that in certain contexts where the speaker needed to persuade his audience of his political decisions and make them share the responsibility of the consequences arising from them, he would tend to use certain pronouns, such as the inclusive plural, over others. Finally, the researcher concluded that the use of personal, special, temporal, and discoursive deixis was utilized by the speaker in a way to move around the elements of the context inside or outside the deictic center of his speeches. Finally, the researcher concluded that the variation of speeches' audience 
and venue affected the choice of deictic expressions in President Trump speeches.

Mwinwelle, Adukpo, and Mortey [16] examined the use of deictic expressions in the concession speeches delivered by John Mahama and Akuffo Addo in the presidential election that took place in Ghana in years 2012 and 2016. The results revealed that both speakers used first person pronoun both singular and plural to positively position themselves in relation to their parties despite their defeat. Addo manipulated the deictic center in a way to distance himself and his party from the defeat while making sure not to imply disrespect to the court's ruling. On the other hand, Mahama reacts to the defeat by recounting his own achievements thus enhancing his, and his party's public image.

\subsection{Framework}

Van Dijk [19] believes that politics and the ideologies underlying its practices are mainly discoursive. He argues that only through discourse these ideologies are observable and may be explicitly stated. In his discussion of manipulation employed in political discourse, he argues that manipulation involves having power of one interlocutor, the speaker, over others, the audience, and that by abusing this power, the speaker can force his ideologies and/or actions on the manipulated audience, mainly by virtue of them not having access to natural sources of information regarding the issue, which makes them compelled to believe or act as desired. Furthermore, the assumption that speakers of a language share some sort of a mental model of discourse accounts for the fact that audiences are usually capable, whether consciously or otherwise, of decoding implied messages in a delivered text [20]. Implication of messages can take the form of using specific deictic expressions where other could have been used.

Persuasion, on the other hand, is manipulation minus the negative connotation. In persuasion, the audience are given the choice of agreeing or otherwise disagreeing with the argument put forward by the speaker [18]. In the political discourse under investigation, persuasion, rather then manipulation, is assumed since no course of action or believe was needed as an outcome of the speech. Furthermore, the audience -who were the international military troops- were assigned a mission agreed upon by many UN governments, so encouraging them, rather than having their approval, was most probably the purpose of this speech.

That being stated, it gives us no choice but to tackle this text under the umbrella of critical discourse analysis CDA, which is the area usually concerned with political issues and ideologies [21]. When using CDA tools, the researcher usually attempts to analyze the structure of political discourse such as biased lexical items, active and passive syntactic structures, pronouns, metaphors, and different implications [19]. All of these structural elements can only be interpretable in relation to the political context where they were produced (ibid). In critical discourse analysis, the focus is not only on the linguistic items and the role the speaker intends them to play, but also on the way they are received and interpreted by the audience [5]. Thus, in the present paper, the focus of analysis would be on personal pronouns and the possible underlying reasons for using certain ones in specific contexts, and the expected effect of such uses on the audience.

According to Levinson [14], almost all utterances, not only deictic expressions, have a sense of context-dependency, and therefore, their meaning cannot be entirely comprehended without referring to the context in which they were produced. This is, partly, caused by the fact that most utterances must have tense, and that tense is very much related to a specific time and context which contributes to the interpretation of that utterance. Therefore, I find it rather necessary, every now and then, to include certain external political and regional facts from the time the speech was delivered in order to arrive at a better understanding of the circumstances and better interpretation of the text.

The framework adopted here for examining deictic expressions is the traditional classification of deixis elaborated by Levinson [14]. The author [14] defines five deictic categories: person, place, time, discourse, and social. What matters to us here is the one related to personal deixis which [14] believes that it refers to the encoding of the participants' roles in a speech event in which a particular utterance is produced. Person deixis includes first person, second person, and third person pronouns, which are defined in accordance with their grammatical classification.

Levinson [14] assumed that all five categories contribute to the notion of deictic center. The central person of the deictic center would be the speaker. The central time is the time at which the utterance was produced. The central place is the speaker's location while producing the utterance. The discourse center is the point at which the speaker is at in his/her speech, and finally, the social center is the speaker's social status in relation to that of the addressee (s) or referent (s).

The Arabic language, which is the language of the speech under investigation, has a three-way pronoun system in relation to the form of pronouns; attached (suffix), unattached (independent), and hidden [23]. The latter refers to cases when the doer of the action is not materialized in the sentence neither in the form of an attached pronoun, one that comes in the form of a suffix, nor in the form of an unattached pronoun, which comes in the form of an independent word. Instead, the doer is implied and its representative pronoun is only understood from the context of the sentence but there is no word or part of word there to symbolize it, thus, it is called a hidden pronoun [23]. These pronouns are further classified in terms of their function into three types: first person, second person, and third person pronouns, similar to the classification of pronouns in the English language. The first person includes seven items based on their position in the sentence, subject vs. object, and their number, singular vs. plural. Second person pronouns include sixteen items in a similar classification to the aforementioned with the addition of the dual class to number classification and the gender factor, male vs. female. Finally, 
third person pronouns include fourteen items classified in the same way as the second person pronouns [26].

Departing from the aforementioned framework, the researcher attempts to analyze the speech of King Fahad to the international troops during the Second Gulf War (1990/91). Under the umbrella of CDA and following the approach adopted by Ivanova [11] and many others, the corpus of deixis will be counted and classified, their respective referents will be spotted, and only those uses with potential hidden non-referential meaning will be further analyzed for possible implied interpretations.

\section{Methodology}

\subsection{Method}

In their explanation of how to analyse political texts, Chilton and Schaffner [4] emphasized that in political speeches and talks small linguistic details do not occur by coincidence. Therefore, in analysing political speech, one must work on these fine details wondering "in which ways can the linguistic choices of the speaker be interpreted as functioning in a politically strategic manner, given the wider political culture and the narrower political context?" (p. 215). thus, two main factors can be seen as affecting the linguistic choice of speakers in political texts; the political culture which includes any circumstances regional or international that might be affecting, whether directly or indirectly, the political behaviour of the speaker, and the political context which refers to the direct setting of the speech. The linguistic details investigated can be related to the pragmatic, semantic, syntactic, morphological, and/or phonetic aspects of the text.

Critical discourse analysis is concerned with explaining how discourse is socially constitutive; i.e. the ways different situations shape discoursive events and get shaped by them at the same time [7]. Therefore, in this analysis of King Fahad's speech, the researcher will keep circulating around certain social, political, regional, and religious principles and beliefs of that time. These principles are thought of as the political culture which got to shape the speech under investigation and at the same time being targeted for change by the speaker.

Since tackling all the linguistic details of a speech of this length would occupy a book, the researcher decided to focus only on the implementation of personal pronouns. The choices of pronouns and the effect of context and on context of such choices will be the focus of investigation in this paper. Bearing in mind that linguistic choices, particularly in political texts, are thought of systemized tools, the researcher believes that the analysis of such a small portion of the text could reveal the speaker's personal, political, and ideological objectives.

\subsection{Participants}

In the speech under investigation, the participants are: the addresser, the addressees, and the observers according to the categorization of Chilton and Schaffner [4]. The addresser is King Fahad bin Abdelaziz, the king of the Kingdom of Saudi
Arabia at that time, who is the political leader who issued the decision of hosting and supervising the international troops in the second gulf war. The addressees are the international troops gathered on the land of Saudi Arabia in preparation for a coming war, in addition to government officials and local and international journalists. The observers include any member of the international community, leaders and peoples, who had interest or was involved in the political dilemma that took place at that time.

\subsection{Procedure}

The speech under investigation was obtained from YouTube website through a video showing the late King Fahad as he was given his speech to the troops [25]. First, the speech was transcribed by the researcher (Appendix A), translated into English (Appendix b), then it was organized in the form of paragraphs based on the ideas contained in the speech. The paragraphs in the translated text correspond to their original counterparts in the Arabic text. Both texts were numbered at the beginning of every paragraph for ease in reference. All references made in the data analysis section are for the original text, not the translation, since the original is the one that was analysed. The English translations was provided to facilitate understanding the gist of the text for non-Arabic speakers.

The researcher, then, read the speech and underlined all the personal pronouns, whether attached or independent, that were used in the speech. They were counted and ordered according to their number of occurrence (Tables 1 and 2). The context of each use was analysed defining the factors that led to using specific pronouns in particular contexts. These factors were both internal, i.e. related to linguistic elements within the text, or external, i.e. related to political and regional circumstances of the time of the speech. The possible desired effect on the audience was calculated based on the political circumstances taking place at that time in addition to the deviation spotted in the use of personal deixis.

\section{Data Analysis}

The speech being analyzed was transcribed from a video clip on YouTube [25] showing the late King Fahad bin AbdulAziz delivering a spontaneous speech to the allied international troops gathered to perform the military operation 'The Desert Strom' during the Second Gulf War. When transcribed, the speech consisted of 1146 words and was divided into fourteen paragraphs based on the transition of ideas (see Appendix A for the transcribed speech and Appendix B for the translated version). Only personal pronouns and their possible political and ideological implications have been investigated in this paper. As important as it is to understand the circumstances surrounding any utterance in order to be able to interpret it comprehensively [8], throughout the upcoming analysis there will be constant reference to the political and regional conditions of that time.

The present paper only focuses on attached and unattached 
(independent) pronouns since they are the ones assumed to potentially carry hidden meanings or be marked for certain semantic features. The hidden pronouns are merely understood based on the syntactic and morphological form of the verb in a given sentence. It is worth mentioning that attached pronouns in the Arabic language are easier to use and more frequent than unattached independent ones [22] $\mathrm{p}$. 9. The discussion of data includes two tables showing the frequency and types of the attached and independent personal pronouns used in the speech under investigation. The order at which they were presented does not signify their importance or number of occurrences. The pronouns were ordered based on their order of occurrence in the text, starting with independent pronouns in table 1 then attached pronouns in table 2. The pronouns are listed in their Arabic forms and their transcribed forms in English letters. Only the pronouns spotted in the examined text were included, which does not imply that the list is inclusive of all Arabic personal pronouns.

\subsection{Analysis of Independent Pronouns}

Table 1. Independent personal pronouns used in the speech.

\begin{tabular}{|c|c|c|c|c|}
\hline Number & Pronoun & English equivalent & Type & Frequency of use \\
\hline 1 & أنا (ana) & I & Independent first person singular & 7 \\
\hline 2 & نحن (nahnu) & We & Independent first person plural & 4 \\
\hline 3 & هو(hoa) & $\mathrm{He} /$ which & Independent third person singular (male) & 6 \\
\hline 4 & هي (hia) & She & Independent third person singular (female) & 3 \\
\hline
\end{tabular}

When attempting to trace the reference of these pronouns to discover any significant use or implication, the following remarks were formed:

1. The first pronoun in the table (أنا) which represents first person (singular) was always used by the speaker to refer to himself mainly in his personal entity not as a representative of the State (Saudi Arabia). In two cases, he mentioned the word 'personally' immediately after the pronoun, and in one case he said "I or the Kingdom of Saudi Arabia" (line 33) implying that he used the pronoun 'I' to refer to himself apart from the State. In other words, he used (or) to separate between himself as a person and his status as the representative of the State. This means that when using the pronoun only, he was referring to his personal experiences and beliefs rather than the stand of the country he ruled. Considering the context and the critical era the whole region was going through, we understand that the speaker tried to emphasize that his decision to get in a war with a neighbor Arab and Muslim country was not based on personal grudge caused by the bad talk coming from President Saddam Hussain, president of Iraq, and the opposing media. By using the pronoun 'I' to represent himself as a person, and at the same time calling the opponent by his name "President Saddam" (line 24) or "Saddam" (line 32) instead of his status as the President of Iraq or the country's name alone (Iraq), the speaker gives his audience the impression that whatever went between him and his opponent was considered personal and that he, the speaker, did not include the State in a war for personal reasons. This result goes in line with that arrived at by Mwinwelle, Adukpo, and Mortey [16] where political speakers manipulated personal pronouns to change the position of elements in relation to the deictic center. Thus, by refereeing to himself and the Iraqi President in their individual entities rather than in their occupational status, the speaker places himself and his opponent outside the deictic center.
2. The second pronoun in the table (نحن) also represents first person but for plural speakers. The pronoun was used in all four cases to refer to the government of the State; whether to talk about the State's responsibilities towards its territory (e.g. line 47) or its reaction to external threats or aggression (e.g. line 10). When using this pronoun, the speaker included himself in the State's actions and responsibilities. In political speech, speakers usually use such a pronoun to manifest affiliation and sense of belonging to the State and its people [10-12].

3. The third pronoun (هو) represents third person (singular male), including animate and inanimate entities like organizations, thoughts, and actions. Actually, only in one utterance it was used to refer to a person (the President of Iraq at that time Saddam Hussain in line 24). This intentional avoidance of referring to the Iraqi President by the appropriate personal pronoun and opting to use the first, and sometimes the full name, instead can be interpreted as an emphasis on holding the President himself, rather than his government or people, responsible and accountable for the actions that led to the political dilemma. This assumption is supported by the fact that the independent third person male singular pronoun was only used once to refer to the Iraqi President while the President's name was used eleven times, sometimes twice in the same sentence (line 5, 6) and sometimes even more (in line 32 it was mentioned three times). In the rest of the cases, the pronoun was used to refer to the UN, good thinking, or the action required from President Hussain. In the latter cases the pronoun is better understood to mean 'which' or 'that' than 'he'. The use of this pronouns did not show any obvious deviation from the norm, except in what looked like intentional lack of use.

4. The fourth pronoun is (هي), it is the last unattached or independent pronoun used in the speech. It is the female counterpart of the previous pronoun. Again, it can be 
used to refer to inanimate entities as well as animate ones. It was used once to refer to the international troops (line 30)- the use of a singular pronoun to refer to a plural name is similar to using singular verbs with collective nouns in English. In another context it was used to refer to the State (line 45), and once to refer to the main principle applied in the State (line 49); i.e. to follow the rules and regulations of the Islamic legislation. The use of this pronoun did not show any deviation from the norm; thus, it is believed that there are no political implications behind the use of this pronoun.

\subsection{Analysis of Attached Pronouns}

The following table shows the types and frequency of attached personal pronouns used in the speech, followed by a detailed analysis of each pronoun.

Table 2. Attached personal pronouns used in the speech.

\begin{tabular}{|c|c|c|c|c|}
\hline Number & Pronoun & English equivalent & Type & Frequency of use \\
\hline 1 & d-(-h) & him & Attached third person singular (male) & 23 \\
\hline 2 & - (-y) & $\mathrm{me} / \mathrm{my}$ & Attached first person singular (used to indicate possession or being the recipient) & 20 \\
\hline 3 & Li(-na) & us & Attached first person plural & 16 \\
\hline 5 & $ت(-$ to $)$ & I & Attached first person singular (used to indicate being the doer) & 4 \\
\hline 6 & Ig(-wo) & They & Attached third person plural & 3 \\
\hline
\end{tabular}

1. The first attached pronoun to occur in the text is (4). It represents third person (singular, male). As mentioned earlier, the Arabic language prefers the use of attached pronouns over independent ones [22] p. 9, which explains the huge difference in number between the use of this pronoun and its independent counterpart. This pronoun was used 23 times. In ten utterances it was used to refer to the Iraqi President at that time Saddam Hussain, (e.g. lines 1, 5, and 27). It was used once to refer to each of the following: the Iraqi people, Arab League, the international community, the present situation (at that time), the Information Minister in KSA, each Arab individual, Allah (God), the attacked State, and every world leader. In the remaining four cases, it was used as an indefinite pronoun similar to the English indefinite pronouns 'someone' and 'something' (lines 21 and 23). The use of this pronoun did not show any deviation from the norm; thus, it is believed that there are no political implications behind the use of this pronoun.

2. The attached first person (singular) (ي) was used in 20 cases. In all the cases, the pronoun referred to the speaker alone, without implying that the State is included. It was used in the context of speaker's personal past experiences with the Iraqi President (line 2, 6), the Saudi Information Minister (line 42), or relating to the speaker's current state during the time of the speech (lines 33, 34, 51, and 57). As mentioned in the table this pronoun sometimes refers to possession or signifies that the speaker is the recipient, so in many instances of use the English equivalent would be me, my or myself. As was the case with the independent pronoun 'I' above, this pronoun was solely used to refer to the speaker in his personal, rather than occupational, status. Thus, whenever this pronoun was used, it represented several personal experiences, stands, or beliefs of the speaker during the time of rendering the speech or prior. Other research supported the assumption that leaders sometimes separate themselves from their people in order to justify certain social and political decisions and to persuade their people of their actions [17].

3. The attached first person plural pronoun (نا) was used sixteen times in the speech. In all the cases, the speaker was referring to the State as a whole, including its leader, government, and people. Interestingly, in 5 cases which correspond to over $31 \%$ of the uses, the pronoun was attached to a word equivalent to 'have been hurt' to convey the meaning that the State has been attacked. This is probably to emphasize that the damage was not targeting the speaker in his personal status, which if it had been the case would not have justified the gathering of international troops to fight back a neighboring Arab and Muslim country. However, establishing that the attack was directed towards the country as a whole, including the land, people, and government makes the gathering of the troops justified and rather necessary. Similar results were obtained in Ivanova and Khalifa $[11,12]$.

4. The attached third person singular (female) pronoun was used 18 times. In half of the cases the pronoun was referring to the State or something related to it. In two other cases, the pronoun was referring to Kuwait, the attacked country. When we know that this pronoun was used in object position (the recipient) in all of its occurrences, it implies that the speaker wanted to convey the proposition that the two countries, Saudi Arabia and Kuwait, did not initiate any action of war and that the gathering of the troops was a mere reaction to a harm that has already been done to both countries. Bearing in mind the regional reluctance towards Saudi Arabia's decision of hosting international troops, including some non-Muslim ones, to get in a war against an Arab and Muslim country, we understand that positioning these two attacked countries in the recipient position within the deictic center functions as an implied justification of the State's action and encouragement for the gathering Arab and Muslim 
troops in their coming war. Implementing personal pronouns in political speech to justify political and social actions is an observed pattern in the study of political discourse analysis [2].

5. The attached first person pronoun $(\uplus)$ was used four times all referring back to the speaker. In three of these uses it was attached to another word to mean 'I have mentioned', and in the remaining case it was attached to a word to mean 'I found'. The use of this pronouns did not show any deviation from the norm; thus, it is believed that there are no political implications behind the use of this pronoun.

6. The last pronoun to be discussed here is $(\mathrm{l} g)$, which is the third person plural pronoun. It was used 3 times. In two cases it referred to the journalists present at the time of the speech, and once to world leaders. The use of this pronouns did not show any deviation from the norm; thus, it is believed that there are no political implications behind the use of this pronoun.

\subsection{General Remarks}

1. There is an observed pattern in the choice of the first person singular pronouns which refer to the speaker in his personal status, first person plural pronouns which refer to the speaker and the State, and third person pronouns which refer to the State alone. The speech was started and ended with first person singular pronouns. The same pronouns (equivalent to $\mathrm{I} / \mathrm{me}$ ) were also used in almost the exact middle of the speech. In between, the other two types; first person plural and third person were used with a clear preference of the first person plural pronouns (equivalent to we/us).

2. The first person singular pronouns were used in two contexts; when referring to personal experiences either with the Iraqi President or with media channels, and when referring to the speaker's ongoing speech. In using these pronouns, the speaker attempted partial separation from his status as the King and adopted a more personalized stand towards the issue, which is a typical use of this pronoun in political speeches [9].

3. The use of first person plural pronouns was always related to an international stand of the State, emphasizing that the speaker includes himself in the moral responsibility of the stands taken by the State or by other countries towards the State. Positioning oneself with one's political affiliation through the use of certain deictic expressions in particular contexts was observed in several political speeches [16].

4. The contexts where third person pronouns were used included mentions of certain domestic or external policies of the State, the status of the State as a member of the United Nations, international stands of the State whether towards the Iraqi invasion or other countries. In these instances, the speaker excluded himself from the state and attempted a more non-biased perspective separating his personal experiences with the Iraqi President and other opposing countries from the decision taken regarding the upcoming war. This exclusion implied in a way that the decisions that were taken regarding hosting the international troops and responding to the Iraqi invasion with war were not based on personal grudge or emotional bias rather they were necessary to ensure the solidarity of the State as an independent member of the international community. Employment of personal pronouns in political speech to justify political and social actions is a common pattern [2].

\section{Conclusion}

It is interesting how the use of personal pronouns can reveal hidden meanings other than mere reference to specific antecedents in the context. In this paper, the analysis focused on the use of personal pronouns in the speech of the late King Fahad bin AbdulAziz, the King of Saudi Arabia at the time of the Second Gulf War (1990/1991) to the international troops gathered on the Saudi land to free the State of Kuwait from the invasion of its neighbor State.

The most prevalent of all was the difference in use between the attached and unattached forms of first person singular and plural pronouns. The attached first person plural pronoun was mainly used to refer to the State; including government and people. It was used to highlight the bad effect of the Iraqi invasion and justify the major procedure that was carried out to refute it. When the pronoun was used in its unattached version, which is more obvious in speech since it appears as an independent word rather than a suffix, it referred to the government, its responsibilities, and its reaction.

The two Arabic pronouns representing first person singular were always used to refer to the speaker only, mainly relating to his personal experiences with the Iraqi president at that tim. In some instances, the speaker used an additional phrase to emphasize that he was referring to himself as an individual rather than his status as the King. This might be caused by the fact that the speech was a spontaneous one that was not previously prepared; and therefore, was relying on personal knowledge and experience rather than on numbers and statistics. On the other hand, using collective plural pronouns was implemented in a way to invoke the sense of solidarity and unity with the people of the country. This pattern of use is typical to most political speeches that have been studied so far $[9,10,16]$.

One last point that is worth mentioning is that the number of times the speaker referred to the president of the invading country in full name is equivalent to the number of times he referred to him using some kind of a pronoun; eleven times in first or full name and eleven in pronouns. Although it is always easier and linguistically preferred to use pronouns when the referent is clear and has been mentioned earlier, the speaker's attempt to use the full name recurrently must not be thought of as unintentional. This was probably caused by the speaker's intention to sperate the president of the invading country from the country itself, i.e. the government and the 
people. Thus, this linguistic maneuver successfully conveyed the message that the Iraqi State and people are still neighbors and respected, and that the invasion was caused by the President's personal bad judgment.

Therefore, assuming the principles of critical discourse analysis regarding the relation of power, politics, ideologies, society and discourse $[19,21]$, it is concluded that in the text under investigation, just like in many others $[17,6,2]$, the use of deictic expressions was intended to persuade the receiving audience of the speaker's ideas and to rearrange the deictic center in a way that places the speaker and his government and people in the recipient reactive position rather than the initiating agent. This was mainly carried out by diversifying the use of personal pronouns in a way that conveys the message of separating personal experiences and benefits from governmental military actions to ensure the best interest of all the involved peoples of the countries who took part in that historical war.

\section{Appendix}

\section{Appendix A: Transcription of King Fahad's Speech to the Military Troops}

سنين و انا لم يفوت يوم او يومين الا و اجد مكالمة من الرئيس صدام و 1 وبر 1

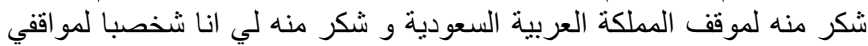
مed

هل هذه المو اقف اللي فات عليها سنين طويلة الى ان انتهت بالاعتداء على 3

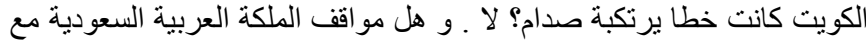

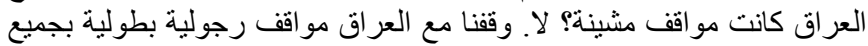

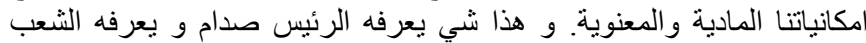

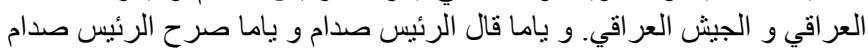

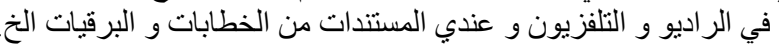

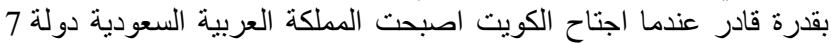

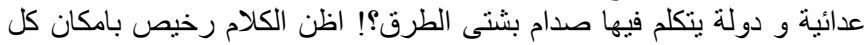

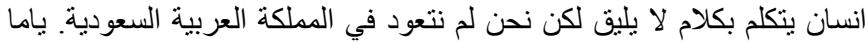

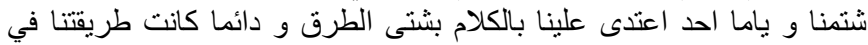

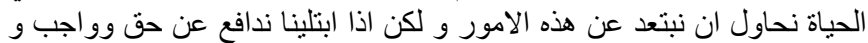

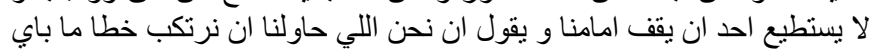

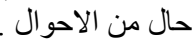

فالحديث عن موضوع الكويت و العر اق حديث طويل عريض و ذكرت ان 11

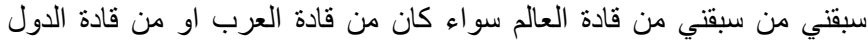

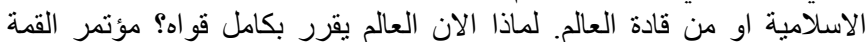

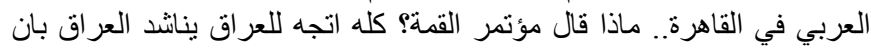

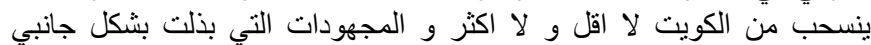
مجهودات منو اصلة لم تحقق شي و المؤتمؤات الاسلامية ناشدت لات الرئيس صدام حسين و لم تحقق شي.

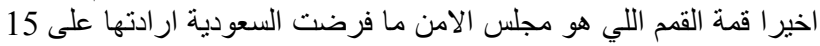

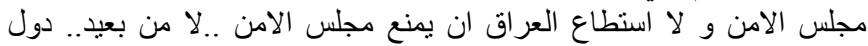

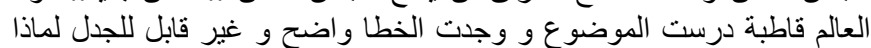

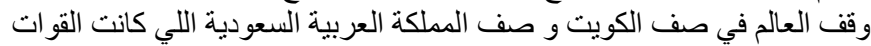

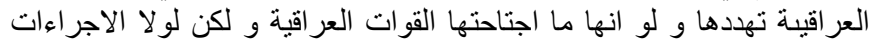

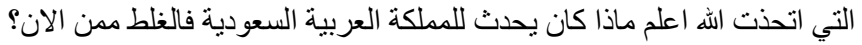

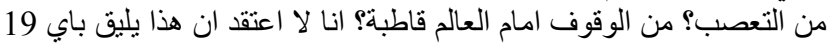

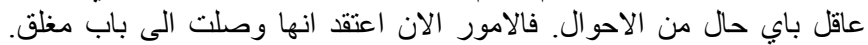

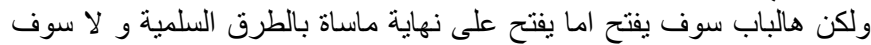

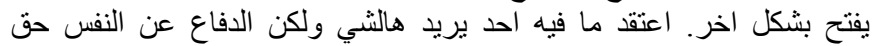

مشروع. لا يسنطيع احد ان يقول ان الدفاع عن النفس مو حق مشروع. بلد

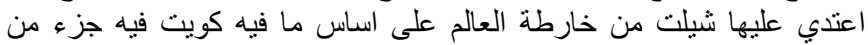

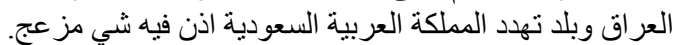

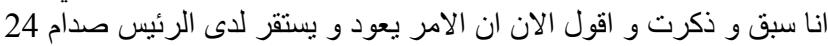

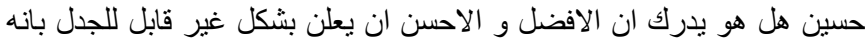

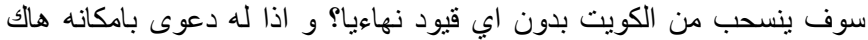

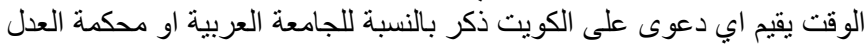

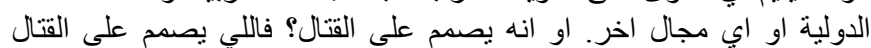

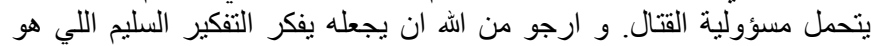
الافضل و الاحسن و هو الحس الحكل الأمثل.

و اظن قادة العالم و الرئيس بوش صرح تصريح بشكل و اضح جدا.

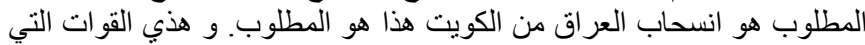

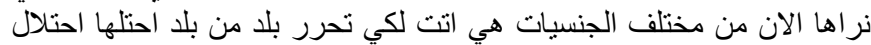

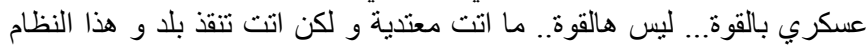

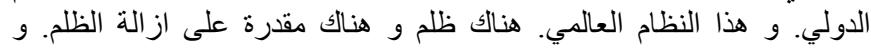

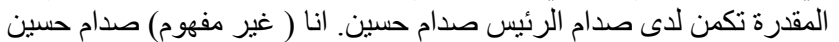

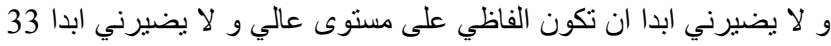

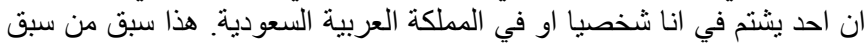

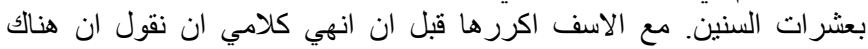

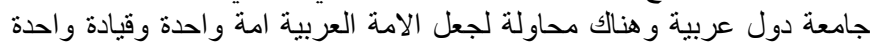

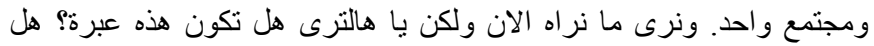

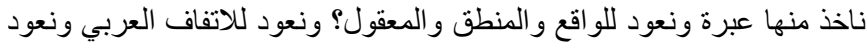

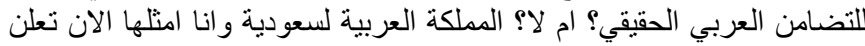

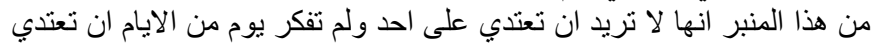

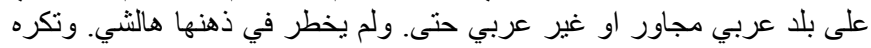

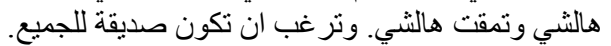

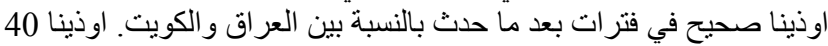

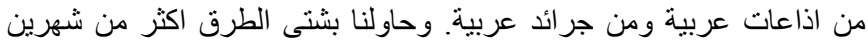

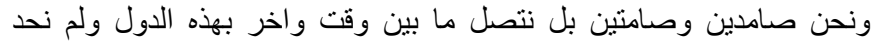

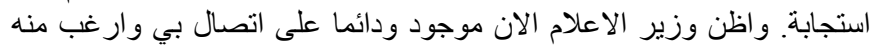

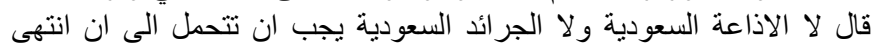

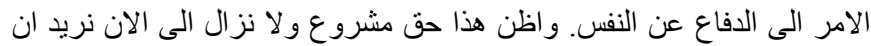

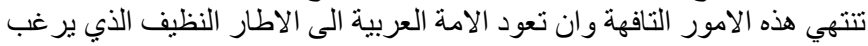

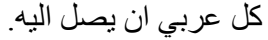

اما المملكة العربية السعودية فهي معروفة تماما بلا ملتزمة بكتاب الله 45

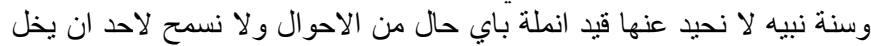

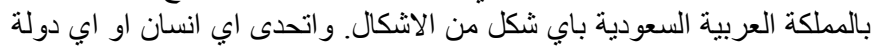

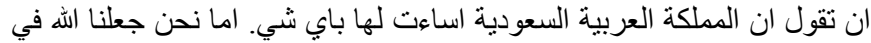

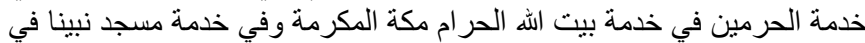

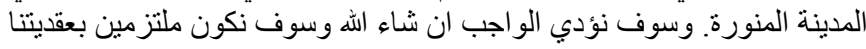

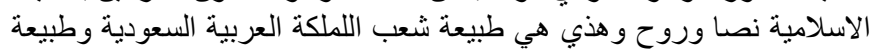

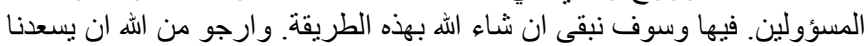

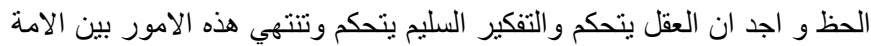
العربية.

وشكرا لسمو الامير سلطان وتمنياتي الطيبة لجميع الجيوش التي اتت 51 التئل

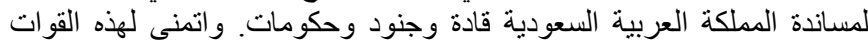

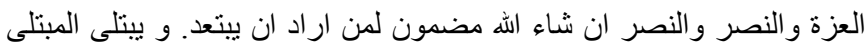

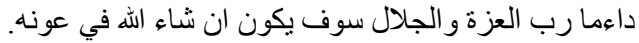

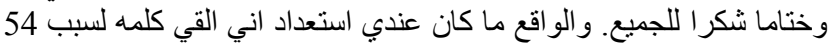

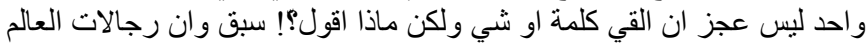

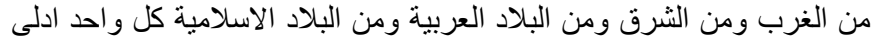

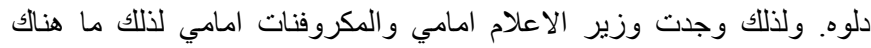

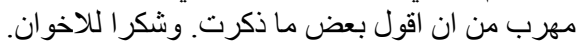

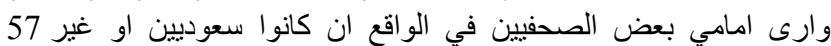

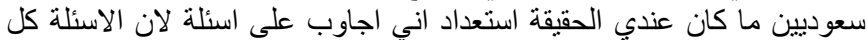

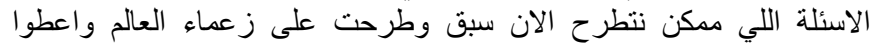

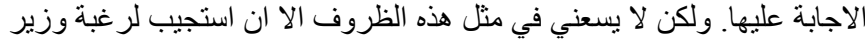


الاعلام واصدقاءنا من الصحفيين الموجودين الان سواء كانو المن البلاد العربية

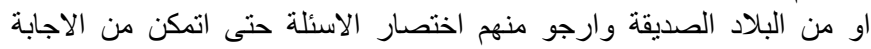
وشكر ا.

\section{Appendix B: English Translation of the Speech}

1 For many years there was not a day that passed without a call from President Saddam thanking me for the stand of Saudi Arabia and thanked me to me personally for things I did for him.

4 Is this attitude that lasted for many years until the end of the attack on Kuwait was a mistake committed by Saddam? No. Are the stands of the Kingdom of Saudi Arabia with Iraq shameful? No. We stood with Iraq heroically manly offering all our material and moral capabilities. This is something President Saddam knows and the Iraqi people and the Iraqi army know. President Saddam had admitted that many times even on radio and television, and I have documents from speeches, cables, etc.

10 Suddenly, when he invaded Kuwait, Saudi Arabia became a hostile state and a state that Saddam speaks of badly ?! I think this is cheap. Everyone is capable of using inappropriate words, but we are not used to doing that in Saudi Arabia. He cursed us and assaulted us repeatedly, but we always try to stay away from these things, but if we are attacked, we will defend. It is our right and no one can say that it is our fault.

15 Talking about the issue of Kuwait and Iraq is a long talk and some of the world leaders, whether they were Arab leaders, leaders of Islamic countries or world leaders have talked about this issue before me. Why now the world decides in full force? Arab summit in Cairo. What did the summit say? All appealed to Iraq to withdraw from Kuwait, and efforts that have been made on the side of summit continuously did not achieve anything, and the Muslim congresses appealed to President Saddam Hussein and did not achieve anything.

22 Finally, the Ultimate Summit, which is the Security Council, Saudi Arabia did not impose its will on the Security Council and Iraq could not prevent the Security Council. All the countries of the world examined the issue and found that the assault was clear and indisputable. Why did the world side with Kuwait and the Kingdom of Saudi Arabia, which was threatened by Iraqi forces, and even if it was not invaded by Iraqi forces, but without the precautions taken, only God knows what would have happened to Saudi Arabia, whose mistake is it now?

28 It results from standing against the whole world? I do not think this is acceptable by any sane person in any way. Now things are thought to have reached a dead end. But this all shall end either peacefully or tragically. I believe no one wants the tragic end but defending one's state is a legitimate solution. No one can say that self-defense is not a legitimate right. A country attacked, removed from the map of the world claiming that Kuwait is part of Iraq, and a country threatening Saudi Arabia. This is very annoying.

34 I have already said that it is up to President Saddam Hussein to realize that it is better to declare indisputably that he will withdraw from Kuwait without any restrictions at all? If he has a complaint, he can take it against Kuwait to the Arab League, the International Court of Justice or to others. Or is he determined to fight? Those who are determined to fight bear the responsibility of fighting. I ask God to make him take the right decision which is for the best and the perfect solution.

41 I think world leaders and President Bush made a very clear statement. What is required is the withdrawal of Iraq from Kuwait. And these forces that we see now from different nationalities came to liberate a country from a country that invaded it. They did not come as aggressors. They came to save a country, and the international system, and world order. There is injustice and there is the ability to remove injustice. The ability lies with Saddam Hussein. I am (incomprehensible) Saddam Hussein

48 It never hurts me to speak up politely, and it never hurts me when anyone is cursing me or Saudi Arabia. This has already been going on for decades. Unfortunately, I repeat it before I finish my speech that there is an Arab League

There is an attempt to make the Arab nation one nation, one leadership, and one community. But see what happens now!! , however is this a lesson? Do we take a lesson from it and get back to reality, logic and reason? And we return to the Arab convention and return to true Arab solidarity? or not? The Kingdom of Saudi Arabia, which I represent now, announces from this rostrum that it does not want to assault anyone and has never thought of assaulting a neighboring Arab or even non-Arab country. We hate the act of assault, and want to be friendly to everyone.

59 We have been hurt many times after what happened between Iraq and Kuwait. We were hurt by Arab radio and from Arab newspapers. We have tried in various ways for more than two months and we are steadfast and silent, even more we contacted them from time to time and did not receive any response. I think the Information minister is present and always in contact with me and I want him to say... both the Saudi radio and the Saudi newspapers should tolerate until it ends up in self-defense. I think this is a legitimate right and we still want to end these trivial things and bring the Arab nation back to the united framework that every Arab wants.

68 As for Saudi Arabia, it is well known as a country that is committed to the Book of Allah and the Sunnah of the Prophet. I challenge any human being or any country to say that Saudi Arabia has assaulted it in any way. God made us in the service of the Two Holy Mosques in the service of the Holy House of Mecca and in the service of our Prophet's Mosque in Medina. We will do our duty, God willing, and we will be committed to our Islamic text and spirit and this is the nature of the people of Saudi Arabia and the nature of officials here. We will keep it this way. I ask God to grant us good luck and I find that the mind controls and sound thinking controls and ends these things among the Arab nations.

78 Thank you to His Royal Highness Prince Sultan and my good wishes to all the armies that came to support Saudi 
Arabia leaders, soldiers and governments. I wish these forces pride and victory. And God always be by the side of those in need.

82 At the end, I thank you everyone. Indeed, I was not prepared to give a speech not because I am incapable of delivering a speech, but there is actually nothing to say. Previously, the leaders of the world from the West, from the East, from the Arab countries and from the Islamic countries all participated with their points of view. However, I found the Minister of Information in front of me and the microphones in front of me so I had to say something. Thank you my brothers.

89 And I see some journalists in fact, whether they are Saudis or non-Saudis, I was not planning to answer any questions. But in such circumstances, I can only comply to the wishes of the Minister of Information and our friends the journalists, whether they are from Arab countries or from friendly countries. I ask them to shorten the questions so that I can answer.

\section{References}

[1] Adegoju, A. (2014). Person deixis as discursive practice in Nigeria's "June 12" conflict rhetoric. Ghana Journal of Linguistics, 3 (1), pp. 45-64. Available at: https://www.ajol.info/index.php/gjl/article/view/107180.

[2] Carreon, J. \& Svetanant, C. (2017). What Lies Underneath a Political Speech? Critical Discourse Analysis of Thai PM's Political Speeches Aired on the TV Programme Returning Happiness to the People. Open Linguistics, 3 (1), pp. 638-655. Retrieved 29 Sep. 2019, from doi: 10.1515/opli-2017-0032.

[3] Chilton, P. (2004). Analysing Political Discourse Theory and practice. London: Routledge.

[4] Chilton, P. and Schaffner, C. (2007). Discourse and politics. In: T. Van Dijk (Ed.), Discourse as Social Interaction. London: Sage Publication Ltd. pp. 206-230.

[5] El Saj, H. (2012). Discourse analysis: Personal pronouns in Oprah Winfrey hosting Queen Rania of Jordan. International Journal of Social Science and Humanity, 2 (6), pp. 529-532. DOI: 10.7763/IJSSH.2012.V2.163.

[6] Eragbe, C. and Yakubu, S. (2015). The use of deixis and deictic expressions in Boko Haram insurgency reports: A study of selected Boko Haram insurgency reports by the media. Research Journal of English Language and Literature (RJELAL), 3 (3), pp. 94-101. Available at: http://www.rjelal.com [Accessed 12 Jun. 2018].

[7] Fairclough, N. and Wodak, R. (2007). Critical discourse analysis. In: T. Van Dijk (Ed.), Discourse as Social Interaction. London: Sage Publication Ltd. pp. 258-284.

[8] Gjergji, S. (2015). A pragmatic analysis of the use of types of deixis in poetry and novels of the author Ismail Kadare. Academicus International Scientific Journal, Vol. 12, pp. 134146. Available https://EconPapers.repec.org/RePEc:etc:journl:y:2015:i:12:p:1 34-146 [Accessed 12 Jun. 2018].

[9] Hakansson, J (2012). The use of personal pronouns in political speeches: A comparative study of the pronominal choices of two American presidents (unpublished paper). Linnaeus University.

[10] Hamdaou, M (2015). The Persuasive Power of Person Deixis in Political Discourse: The Pronoun 'We' in Obama's Speeches About the 2007-2009 Financial Crisis as an Example. The European Conference on Arts \& Humanities 2015 Official Conference Proceedings. University of Sfax, Tunisia.

[11] Ivanova, A. (2016). Deixis and its role in defining rhetorical space. Revista Signos, [online] 49 (92), pp. 329-349. Available at: https://scielo.conicyt.cl/scielo.php?script=sci_abstract\&pid=S 0718-09342016000300004\&lng=es\&nrm=iso\&tlng=en [Accessed 12 Jun. 2018].

[12] Khalifa, R. (2018). A Deictic Analysis of the Political Discourse of some of Donald Trump's Presidential Speeches Based on the Discourse Space Theory. Sahifatul-Alsun. 34. 40-71.

[13] Khalil, H. (2014). Discourse deixis in the American political speeches. Journal of College of Education for Women, 25 (2), pp. 525-535. Available at: https://www.iasj.net/iasj?func=fulltext\&aId=91648 [Accessed 12 Jun. 2018].

[14] Levinson, S. (1983). Pragmatics. Cambridge: Cambridge University Press.

[15] Miller, J. (1991). 'CONFRONTATION IN THE GULF; Saudi King Says He Expects Iraq to Yield'. New York Times. 7 Jan. Retrieved from https://www.nytimes.com/1991/01/07/world/confrontation-inthe-gulf-saudi-king-says-he-expects-iraq-to-yield.html.

[16] Mwinwelle, P; Adukpo, J \& Motey, F (2019). Analysis of the Use of Personal Deixis in Concession Speeches. International Journal of art, Language \& Linguistics. 1 (1), pp. 11-23.

[17] Quinto, E. (2014). Stylistic analysis of deictic expressions in president Benigno Aquino III's October 30th speech. 3L: Language, Linguistics, Literature: The Southeast Asian Journal of Language Studies, 20 (2), pp. 1-18. Available at: $\mathrm{http}: / /$ ejournal.ukm.my/31/article/view/5140.

[18] Van Dijk, T. (2006a). Discourse and manipulation. Discourse and Society, 17 (2), pp. 359-383. Available at: $\mathrm{http}: / /$ journals.sagepub.com/home/das.

[19] Van Dijk, T. (2006b). Politics, ideology, and discourse. Encyclopedia of Language \& Linguistics, pp. 728-740.

[20] Van Dijk, T. A. (2010). Discourse, knowledge, power and politics Towards Critical Epistemic Discourse Analysis. In C.J. Hart (Ed.), Critical Discourse Studies in Context and Cognition. Amsterdam: Benjamins, pp. 27-64.

[21] Van Dijk, T. (2015). Critical Discourse Analysis. In: D. Tannen, H. Hamilton and D. Schiffrin, (Ed)., The Handbook of Discourse Analysis. Chichester: Wiley Blackwell, pp. 466485 .

[22] Alatwi, A. (1995). Independent pronoun in Quran. Masters thesis. Imam Mohammad Ibn Saudi Islamic University.

[23] Jabir, W. (2011). Pronouns. School Arabia. Available at: http://www.schoolarabia.net/arabic/damaer/damaer1.htm [Accessed 12 Jun. 2018]. 
[24] Laurent, E. \& Salinger, P. (1993). Gulf war: Secret file (Arabic translation). Beirut: All prints distributers and publishers.

[25] King Fahad Bin AbdulAziz speech to the international troops. (2008).
Available https://www.youtube.com/watch?v= 5iIQWM4Ra8 [Accessed 12 Jun. 2018].

[26] Fawziah, D. (2010). Arabic pronouns: Concept and function. Journal of College of Arts and Humanities, vo. 6. Mohammad Khunaiser University: Baskarah. 